\title{
Zamiast wstępu
}

Zacznijmy od słów Stainera: „W przekładzie objawia się szczególnie dramatycznie dialektyka jednostkowości i mnogości. W pewnym sensie każdy akt przekładu jest próbą unicestwienia wielości i ponownego doprowadzenia różnych obrazów świata do doskonałej harmonii. W innym stanowi próbę odtworzenia kształtu znaczenia, znalezienia i usprawiedliwienia odmiennego stwierdzenia. [...] Toteż przekład nie jest wyspecjalizowaną, drugorzędną działalnością na styku pomiędzy językami. Jest nieustanną, konieczną egzemplifikacją dialektycznej, jednocześnie spajającej i dzielącej natury mowy" (Stainer 1998/2000: 327)'. Tak ujęty przekład jest zjawiskiem dynamicznym, zmiennym $\mathrm{w}$ czasie i przestrzeni, wymykającym się wszelkim determinizmom. Dylematem każdego tłumacza, rozpiętym między paradygmatami kultur wyjściowej i docelowej. Ale również wyborem nowego (?) spojrzenia na przekład jako zjawisko, proces i produkt, a także na dzisiejszą sytuację tłumacza. Bo dylemat jest fundamentem jego pracy, który łączy wszystkie przekłady niezależnie od dziedziny, stawiając znaki zapytania $\mathrm{w}$ wielu kwestiach: statusu tłumaczenia wobec oryginału, statusu i roli tłumacza, procesu kształcenia tłumaczy, kategoryzacji przekładu, a także problemów w przekładzie pisemnym, ustnym i audiowizualnym. Rozważania na ten temat składają się na trzeci już tom z cyklu Norma a uzus, który oddajemy do rąk Czytelnika.

Tom otwiera artykuł Teresy Tomaszkiewicz (w numerze kolejność tekstów alfabetyczna) pt. Dylematy nauczyciela akademickiego kierującego seminarium magisterskim $w$ ramach studiów thumaczeniowych, poświęcony roli seminarium magisterskiego i pracy magisterskiej $\mathrm{w}$ procesie kształcenia tłumaczy $\mathrm{w}$ ramach studiów II stopnia. Bazując na własnym doświadczeniu, autorka dzieli się dylematami związanymi z koniecznością uświadomienia studentom znaczenia działań badawczych podejmowanych $\mathrm{w}$ trakcie pracy nad rozprawą magisterską dla ich przyszlej praktyki zawodowej na rynku tłumaczeniowym. Autorka dochodzi do wniosku, że niezależnie od tematu pracy magisterskiej, umiejętności nabyte $\mathrm{w}$ trakcie jej redakcji: jak pozyskiwanie, porządkowanie i hierarchizowanie informacji, rozwiązywanie problemów, planowanie działań w czasie, zarządzanie własną pracą, samodyscyplina, wpisują się w szeroką paletę umiejętności pożądanych nie tylko w zawodzie tłumacza.

Również artykuł Malgorzaty Jokiel pt. Norma i uzus $w$ dydaktyce przekładu specjalistycznego wobec oczekiwań rynku pracy pozostaje $\mathrm{w}$ sferze dydaktyki tłumaczenia. Poświęcony jest specyfice dydaktyki akademickiej tłumaczenia ustnego $\mathrm{w}$ rejestrach specjalistycznych $\mathrm{z}$ zakresu ekonomii z uwzględnieniem dwóch form przekładu: konsekutywnego oraz a vista. Biorąc za punkt wyjścia charakterystykę języka ekonomicznego z perspektywy przekładoznawczej, na podstawie własnego doświadczenia dydaktycznego oraz translatorskiego (uzus), autorka podejmuje próbę zróżnicowania wymogów, celów i metodyki postępowania w przypadku wspomnianych form translacji ustnej, zarówno przy uwzględnieniu ich specyfiki, jak i uwarunkowań kształcenia uniwersyteckiego (norma), wynikających m.in. z Polskiej Ramy Kwalifikacyjnej, mając na uwadze realia rynkowe przyszlej kariery zawodowej studentów oraz zawarte $\mathrm{w}$ ogłoszeniach o pracę wymogi i oczekiwania ze strony potencjalnych pracodawców, by w końcowej części sformułować wnioski i postulaty dotyczące optymalizacji nauczania przekładu.

\footnotetext{
${ }^{1}$ Steiner G. 1998/200o, Po wieży Babel. Problemy języka i przekładu. Kraków: Universitas.
} 
Tłumaczeniu ustnemu poświęcony jest także kolejny artykuł pt. Tłumaczenie środowiskowe a biznesowe - status i rola ttumacza, w którym Katarzyna Krajewska ukazuje wyraźne różnice między tłumaczeniem środowiskowym a szeroko pojętym tłumaczeniem 'biznesowym', odzwierciedlające się na poziomie ról odbiegających od ról tradycyjnie przypisanych tłumaczom środowiskowym i konferencyjnym. Autorka analizuje szereg sytuacji, w których od tłumacza oczekuje się podjęcia działań wykraczających poza przyjęte standardy zawodowe, stawiając szereg pytań dotyczących czynników sytuacyjnych, wpływających na rozmycie dotychczasowych funkcji tłumaczy i ich statusu.

Kolejny artykuł pt. Ttumacze bez Granic a status ttumacza, autorstwa Patrycji Masłowskiej, ukazuje wielorakie aspekty pracy tłumaczy pisemnych i ustnych, zaangażowanych w działalność tytułowej organizacji. Autorka charakteryzuje różne typy działań podejmowanych przez Tłumaczy bez Granic w ramach przekładu pisemnego i ustnego, następnie podejmuje próbę analizy wpływu ich zinstytucjonalizowanej działalności na status tłumacza. Próbuje też znaleźć odpowiedź na pytanie, na ile wobec nieodpłatnego charakteru usług tłumaczeniowych świadczonych nierzadko w bardzo trudnych warunkach, wolontariusze mogą czerpać satysfakcję z wykonywanej pracy.

Patrycja Bobowskia-Nastarzewska poszerza spektrum dylematów tłumaczenia tekstów specjalistycznych o problemy związane z tłumaczeniem tekstów naukowych. Celem jej artykułu Rola thumacza pisemnych tekstów specjalistycznych na podstawie własnych doświadczeń traduktologicznych jest określenie roli tłumacza w procesie tłumaczenia tego rodzaju tekstów. Analiza koncentruje się na tekstach filozoficznych przetłumaczonych z francuskiego na polski przez autorkę artykułu. Zazwyczaj postuluje się, iż $\mathrm{w}$ tekstach specjalistycznych tłumacz powinien być niewidzialny, a tłumaczenie powinno być transparentne. Jednak z doświadczenia traduktologicznego wynika, że trudno jest spełnić ten postulat, ponieważ osobiste podejście do tłumaczonych tekstów - czynnik emocjonalny, subiektywny - pozostawia ślad w tłumaczeniu. Autorka zgodnie z założeniem Anthony'ego Pyma optuje za tym, by w podejściu do przekładu brać pod uwagę także czynnik ludzki.

Barbara Walkiewicz pochyla się nad problemami związanymi z tłumaczeniem ofert nieruchomości, którym poświęca artykuł pt. Między paradygmatami. Problemy terminologiczne $w$ przekładzie ofert nieruchomości. Po dokonaniu ogólnego porównania stopnia przystawalności tytułowych paradygmatów budownictwa jednorodzinnego i wielorodzinnego w Polsce i we Francji, autorka analizuje przekłady wybranych ofert nieruchomości na j. francuski, wykonane w różnych biurach tłumaczy. W konkluzji stwierdza, że wobec względnej przystawalności obu systemów mieszkalnictwa i szerokiej dostępności źródeł wiedzy na temat charakterystyki poszczególnych jego form, zaobserwowana nieprecyzyjność terminologiczna jest wykładnikiem niskiej kompetencji dyskursywnej tłumaczy.

Przyczyny problemów tłumaczy języka hiszpańskiego stanowią przedmiot rozważań Edyty Faryś-Kwiatkowskiej i Agaty Wolarskiej-Sobocińskiej, zawartych w artykule pt. Geolektalne pułapki języka hiszpańskiego w praktyce przekładu pisemnego i ustnego. Autorki dokonują przeglądu tytułowych pułapek na poziomie semantyczno-leksykalnym, a także fonetyczno-fonologicznym i pragmatycznym, wynikających z policentryczności języka hiszpańskiego. Autorki zapoznają też Czytelnika $\mathrm{z}$ postulowanym od dawna projektem ujednolicenia geolektalnie zróżnicowanego języka hiszpańskiego poprzez stworzenie wariantu neutralnego, niezbędnego szczególnie w przekładzie specjalistycznym, zwłaszcza w dziedzinie nowych technologii, a także w mediach, przemyśle kultury i szeroko pojętych przemysłach kreatywnych. 
Małgorzata Czubińska w artykule Sposoby wykorzystania napisów scenicznych jako metody przekładu spektakli teatralnych w trakcie Malta Festival Poznań 2017 otwiera wątek multimedialności tudzież multimodalności oryginału jako źródło dylematów dla tłumacza. Artykuł na wstępnie zwraca uwagę na rozwój technologiczny oraz wywołanych nim dynamicznych zmian w sposobach komunikacji, który powoduje, że przekładoznawstwo staje $\mathrm{w}$ obliczu konieczności scharakteryzowania wyzwań, które niosą ze sobą nowe metody translacji. Na przykładzie tłumaczenia spektakli teatralnych z wykorzystaniem napisów scenicznych udowadnia, że uzus określony jako sposób opracowania i wykorzystania napisów w konkretnym spektaklu, nie zawsze podąża za zdefiniowaną wcześniej normą. Teatr jest sztuką charakteryzującą się wielowymiarowością i dynamiką, zatem trudno ująć zarówno ją samą, jak i towarzyszący jej przekład w sztywne ramy norm.

Damian Wątrobiński ukazuje Dylemat audiodeskryptora $w$ procesie przekładu audiowizualnego. Artykuł omawia problem przekazu emocji w audiodeskrypcji oraz w związku z tym wskazanie na dylemat towarzyszący tłumaczowi tworzącemu audiodeskrypcję do reprodukcji malarskich. Przekazywanie określonych emocji w audiodeskrypcji może bowiem zostać uznane za niedozwoloną interpretację lub próbę manipulacji uczuciami osoby niewidomej. Kwestia emocjonalności przekazu audiodeskrypcji zostanie przedstawiona na płaszczyźnie teoretycznej, i również za pomocą analizy dwóch audiodeskrypcji, w trakcie tworzenia których audiodeskryptor musiał podjąć decyzję o zastosowaniu w tekście środków językowych i pozajęzykowych implikujących emocje.

Beate Sommerfeld w artykule Ilustracja książek dla dzieci jako źródto dylematów thumacza - na przykładzie dwóch niemieckich przekładów „Le Petit Prince" Antoine'a de Saint-Exupéry'ego analizuje tłumaczenia niemieckich przekładów kanonicznego dzieła Le Petit Prince Antoine’a de Saint-Exupéry'ego. Unaoczniają one dylematy tłumacza $\mathrm{w}$ zetknięciu z intermedialnym charakterem oryginału. Szczególnie w przypadku obierania przez tłumaczy strategii adaptacyjnych oryginalne ilustracje mogą stanowić przeszkodę. Tłumacze i wydawnictwa znajdują różne wyjścia. Przekład Hansa Magnusa Enzensbergera nie uwzględnia znaczenia ilustracji i rozwija się w oderwaniu od nich. Lekceważenie intermedialnego charakteru powoduje znaczne zubożenie oryginału. Natomiast ilustracje do tłumaczenia Petera Sloterdijka współgrają z nowym odczytaniem tekstu.

Artykuł Joanny Bukowskiej Anatomia uczuć $w$ przekładzie. Strategie thumacza $w$ oddawaniu warstwy emocjonalnej tekstu literackiego na przykładzie powieści „Partygirl" Marlene Streeruwitz wskazuje na aspekt emocjonalności tekstu źródłowego i związane $\mathrm{z}$ nią problemy translatorskie. Autorka ma na celu przeanalizowanie warstwy emocjonalnej twórczości prozatorskiej austriackiej pisarki Marlene Streeruwitz na przykładzie powieści Partygirl i jej polskiego tłumaczenia autorstwa Emilii Bielickiej. Artykuł jest próbą odpowiedzi na pytanie, jak dużym wyzwaniem dla tłumacza jest przekład emocji widocznych w literaturze tytułowej pisarki. Tłumacz występuje w dwóch rolach: jako wrażliwy odbiorca tłumacz powinien się wykazać zdolnością odczuwania empatii, i jak dobry negocjator musi umieć przewidzieć reakcje swoich czytelników.

Żywimy głęboką nadzieję, że oddany do rąk Czytelnika trzeci już tom z cyklu Norma a uzus zachęci do dalszych rozważań na temat dylematów w pracy tłumacza pisemnego, ustnego i audiowizualnego, przyczyniając się tym samym do upowszechnienia wiedzy na temat specyfiki zawodu, jak również optymalizacji warunków jego wykonywania. 